\title{
EDUKASI DAN FORMULASI HAND SANITIZER EKSTRAK ETANOL DAUN SIRSAK (Annona Muricata Linn)
}

\section{Education and Formulation of Hand Sanitizer Ethanol Extract of Soursop Leaf (Annona Muricata Linn)}

\author{
Nur Rahmi Hidayati, Bayu Nugroho Eka Seno, Farhan Firmansyah Bachtiar \\ Sekolah Tinggi Farmasi Muhammadiyah Cirebon \\ nurrahmihidayati83@gmail.com
}

\begin{abstract}
ABSTRAK
Pada pandemik Covid-19 yang melanda dunia saat ini pemerintah mengharuskan masyarakat untuk meningkatkan perilaku hidup sehat dengan salah satu indikatornya adalah mencuci tangan. Hand sanitizer merupakan salah satu bahan antiseptik yang sering digunakan masyarakat sebagai media pencuci tangan yang praktis. Pengabdian kepada masyarakat ini bertujuan melakukan pembuatan formulasi sediaan hand sanitizer yang berasal dari Daun Sirsak (Annona muricata L.) dan melakukan edukasi hand sanitizer kepada masyarakat di Kecamatan Mundu, Kabupaten Cirebon. Program kegiatan KKM yang disampaikan menggunakan metode webinar dan sampling hasil hand sanitizer pada tetangga. Hasil yang diperoleh daun sirsak dapat diformulasikan sebagai hand sanitizer sebagai salah satu cara untuk cuci tangan secara praktis dalam menghadapi kondisi pandemi Covid-19. Pelaksanaan webinar menunjukkan respon yang positif dengan adanya interaksi antara peserta dan penyelenggara webinar. Pemberian sampel hand sanitizer kepada tetangga sekitar, tujuannya agar mengetahui formulasi, cara pembuatan, tujuan, kandungan, cara pakai yang baik, dan hal yang perlu diperhatikan sebelum menggunakan hand sanitizer kepada masyarakat, khususnya Kecamatan Mundu, Kabupaten Cirebon.
\end{abstract}

Kata kunci: Hand sanitizer, COVID-19, Kuliah Kerja Mahasiswa

\begin{abstract}
In the Covid-19 pandemic that has hit the world, the government is currently requiring people to improve their healthy lifestyle with one of the indicators is washing their hands. Hand sanitizer is an antiseptic ingredient that is often used by the public as a practical hand washing medium. This community service is aimed at making hand sanitizer formulations derived from Soursop (Annona muricata L.) leaves and providing hand sanitizer education to the community in Kecamatan Mundu, Kabupaten Cirebon. The KKM activity program that is delivered uses the webinar method and the sampling of the results of hand sanitizers to neighbors. The results obtained by soursop leaves can be formulated as a hand sanitizer as a way to wash hands practically in the face of the Covid-19 pandemic conditions. The implementation of the webinar shows a positive response with the interaction between the participants and the webinar organizer. Providing samples of hand sanitizers to neighboring neighbors, the aim is to know the formulation, method of manufacture, purpose, content, proper use, and things that need to be considered before using hand sanitizers to the community, especially Kecamatan Mundu, Kabupaten Cirebon.
\end{abstract}

Keywords: Hand sanitizer, COVID-19, Student Work Lecture 


\section{PENDAHULUAN}

Kesehatan menjadi salah satu hal terpenting yang dapat mempengaruhi kualitas hidup seseorang. Pada pandemik Covid-19 yang melanda dunia saat ini pemerintah mengharuskan masyarakat untuk meningkatkan perilaku hidup sehat dimana salah satu indikatornya adalah mencuci tangan. Mencuci tangan merupakan teknik dasar yang paling penting dalam pencegahan dan pengontrolan infeksi dan juga keadaan sekarang yang mewajibkan masyarakat untuk selalu mengutamakan cuci tangan saat bepergian kemanapun (James, 2008).

Seiring perkembangan zaman kebiasaan mencuci tangan telah teralihkan dengan cara yang lebih praktis salah satunya dengan penggunaan hand sanitizer (Manus, dkk, 2016). Hand sanitizer merupakan salah satu bahan antiseptik yang sering digunakan masyarakat sebagai media pencuci tangan yang praktis (Aminah, dkk, 2018).

Daun sirsak merupakan jenis tanaman yang mengandung flavonoid, saponin, tanin, alkaloid, kalsium fosfor, polifenol, hidrat arang, vitamin A dan vitamin B (Mangan, 2009). Senyawa flavonoid dan polifenol yang merupakan turunan fenol bekerja sebagai antiseptik dan desinfektan sedangkan alkaloid yang bersifat basa memiliki aktivitas bakterisid. Flavonoid berfungsi sebagai antibakteri dan antiseptik yang membentuk senyawa kompleks terhadap protein ekstraseluler yang mengganggu integritas membran sel bakteri. ${ }^{5}$ Daun sirsak terbukti memiliki efek antibakteri salah satunya berefek pada bakteri gram positif yaitu Staphylococcus aureus (Sjahid, 2008).

Seiring perkembangan zaman, dikembangkan juga pembersih tangan non alkohol. Alkohol banyak digunakan sebagai antiseptik /desinfektan untuk desinfeksi permukaan kulit yang bersih, tetapi tidak untuk kulit yang luka (Hapsari, 2015). Selain itu alkohol juga mempunyai sifat iritasi pada kulit, mudah terbakar, dan juga meningkatkan infeksi virus pemicu radang saluran pencernaan, karena itu muncul ide untuk memanfaatkan bahan alami yang dapat mengurangi resiko munculnya penyakit gangguan pencernaan (Cahyani, 2014).

Berdasarkan penelitian yang dilakukan oleh Widyawati, dkk (2017) daun sirsak mengandung senyawa flavonoid, tanin, alkaloid, dan saponin yang dapat dimanfaatkan sebagai antibakteri. Hasil penelitian menunjukkan adanya kemampuan daun sirsak untuk menghambat pertumbuhan bakteri Staphylococcus aureus (Widyawati, 2017).

Pelaksanaan Pengabdian Kuliah Kerja Mahasiswa (KKM) selama masa COVID-19 ini, dilaksanakan melalui sistem daring dengan tetap produktif menciptakan produk yang dapat dimanfaatkan dan dapat mengedukasi masyarakat. Kegiatan KKM ini berupa pengabdian kepada masyarakat terkait pengembangan atau pemberdayaan masyarakat dalam bentuk edukasi pembuatan formulasi sediaan hand sanitizer yang berasal dari Daun Sirsak (Annona muricata L.) dan melakukan edukasi hand sanitizer kepada masyarakat, yang mana saat ini sangat 
diperlukan oleh masyarakat, sehingga dapat dimanfaatkan dengan baik di masa pandemi Covid19 saat ini.

\section{BAHAN DAN METODE}

Metode pelaksanan kegiatan KKM ini yaitu: pertama pembuatan video dilakukan di Laboratorium Farmasetika STF Muhammadiyah Cirebon, oleh Bayu Nugroho Eka Seno, Farhan Firmansyah Bachtiar dengan koordinasi dosen pembimbing lapangan (DPL) KKM Ibu Apt., Nur Rahmi Hidayati, M.Farm, berisi rangkaian pembuatan hand sanitizer yang dilakukan pada bulan Juli 2020. Kedua pelaksanaan edukasi pada masyarakat, dikarenakan kondisi pandemi Covid-19, maka pelaksanaan edukasi kepada masyarakat dilakukan secara webinar pada tanggal 25 Agustus 2020. Dihadiri oleh warga sekitar tempat tinggal mahasiswa, DPL KKM, dan beberapa Dosen STF Muhammadiyah Cirebon. Terakhir tahap ketiga, pemberian sampel hand sanitizer kepada tetangga sekitar tempat tinggal mahasiswa yang dilaksanakan pada 27-29 Agustus 2020. Hand sanitizer yang telah siap digunakan diberikan kepada masyarakat dengan mendatangi masing-masing rumah tetangga sekitar tempat tinggal. Dengan tetap memperhatikan dan mengikuti protokol kesehatan seperti memakai masker dan menjaga jarak.

\section{Alat}

Gelas kimia/beaker glass, mortir, stamper, pipet tetes, gelas ukur, batang pengaduk, oven, timbangan digital, rotary evaporator, waterbath, magnetic stierer, erlenmeyer, cawan uap, kompor listrik.

\section{Bahan}

Ekstrak daun sirsak (Annona muricata Linn), etanol, karbopol, metil paraben (Nipagin), trietanolamin (TEA), gliserin, dan aquadest.

\section{Pembuatan Ekstrak}

Pembuatan ekstrak daun sirsak (Annona Muricata Linn) dengan menggunakan metode maserasi dan menggunakan pelarut etanol $96 \%$ yang didiamkan dalam bejana selama 3 hari. Disaring dan serkai, setelah itu dipekatkan dengan Rotary Evaporator sehingga larutan menjadi lebih pekat, selanjutnya uapkan diatas water bath hingga terbentuk masa kental ekstrak etanol daun sirsak.

\section{Pembuatan Hand Sanitizer}

Menyiapkan Mortir dan Stamper, menimbang Carbopol 940 dan mengambil Aquades dan dimasukkan ke dalam mortir. Menaburkan Carbopol 940 di atas aquadest tersebut setelah 
itu diaduk. Menambahkan TEA lalu diaduk sampai membentuk massa Gel. Menimbang metil Paraben dan Ekstrak etanol daun sirsak. Gerus metil paraben dan ekstrak etanol daun sirsak. Masukan kedalam mortir yang telah terbentuk massa gel lalu aduk hingga homogen. Tambahkan gliserin lalu aduk hingga homogen. Masukan kedalam botol hand sanitizer.

\section{Edukasi Hand sanitizer}

Mengedukasi mengenai tujuan penggunaan hand sanitizer, kandungan dari hand sanitizer, cara pakai hand sanitizer yang baik dan benar serta mengenai hal-hal yang perlu diperhatikan sebelum menggunakan hand sanitizer.

\section{HASIL}

\section{Kegiatan 1 (Pembuatan video Edukasi Proses Pembuatan Hand Sanitizer)}

Kegiatan pengabdian telah selesai dilaksanakan sesuai dengan prosedur yang telah ditetapkan. Kegiatan pertama adalah diawali dengan pembuatan ekstrak daun sirsak (Annona Muricata Linn) dengan menggunakan metode maserasi dan menggunakan pelarut etanol $96 \%$, setelah itu dilanjutkan dengan pembuatan hand sanitizer. Pada kegiatan 1 (pembuatan video edukasi proses pembuatan hand sanitizer), pada Gambar 1 ditampilkan bahan baku serta proses perajangan bahan baku hand sanitizer yang sudah mengalami proses pengeringan. Selanjutnya dilakukan proses penghalusan simplisia daun sirsak dan pemberian alkohol $96 \%$ untuk maserasi simplisia daun sirsak seperti tertera pada gambar 2 dan gambar 3.

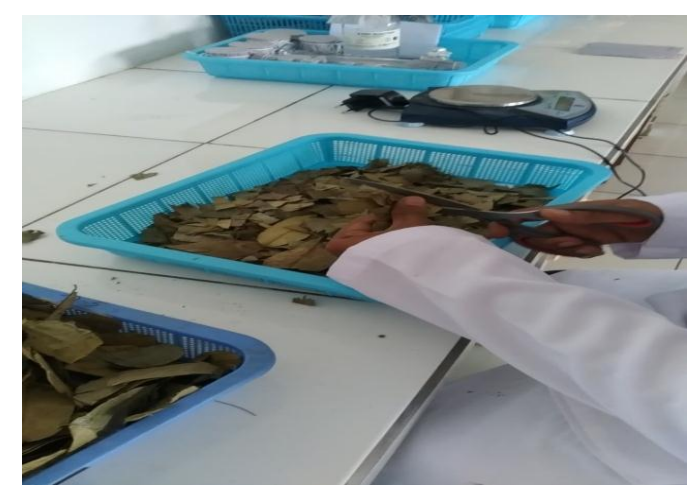

\section{Gambar 1. Proses Perajangan Simplisia Daun Sirsak}




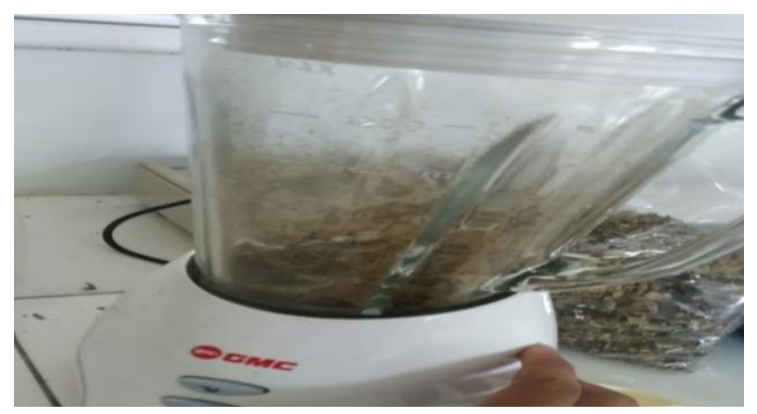

Gambar 2. Proses Penghalusan Simplisia Daun Sirsak

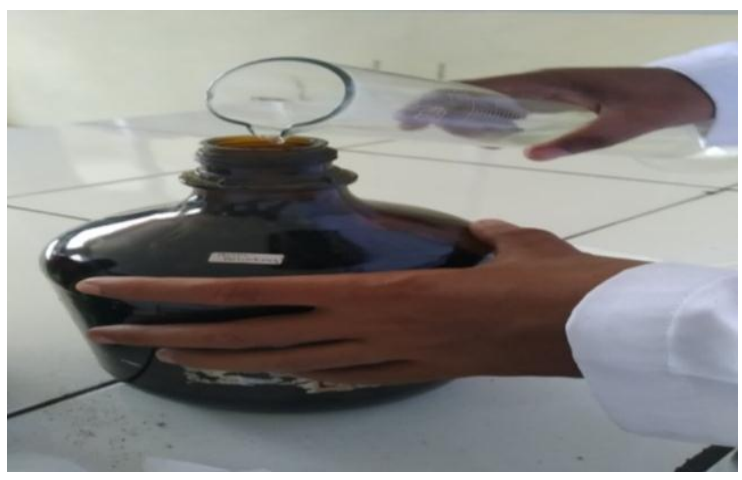

\section{Gambar 3. Proses Pemberian Pelarut untuk Maserasi Simplisia daun sirsak}

Proses selanjutnya adalah penyaringan dan serkai ekstrak, setelah itu dipekatkan dengan Rotary Evaporator sehingga larutan menjadi lebih pekat, selanjutnya uapkan diatas water bath hingga terbentuk masa kental ekstrak etanol daun sirsak. Proses tersebut tertera pada gambar 4 dan 5 dan 6.

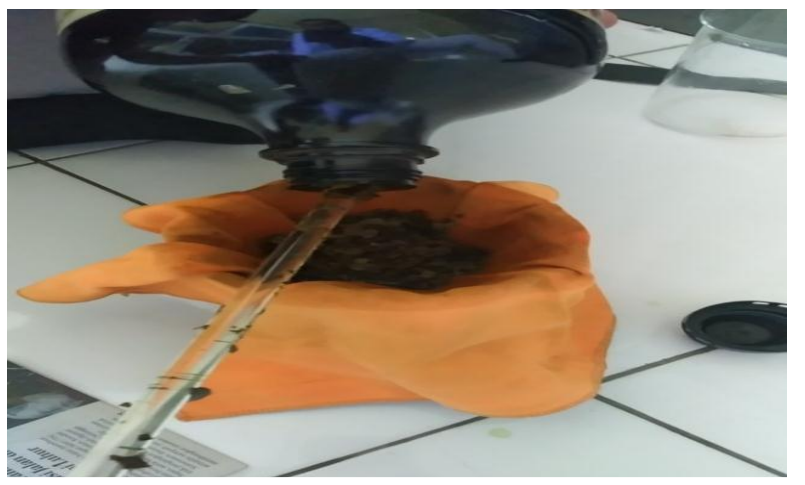

Gambar 4. Proses Penyaringan Hasil Maserasi Daun Sirsak 


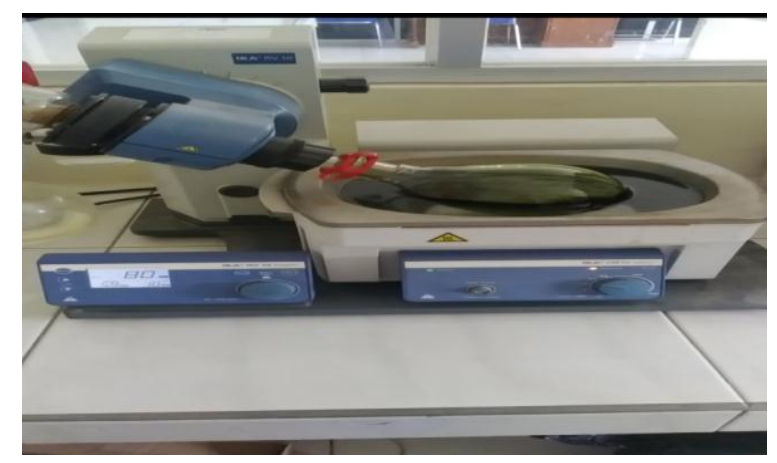

Gambar 5. Proses Pemekatan dengan Rotary Evaporator

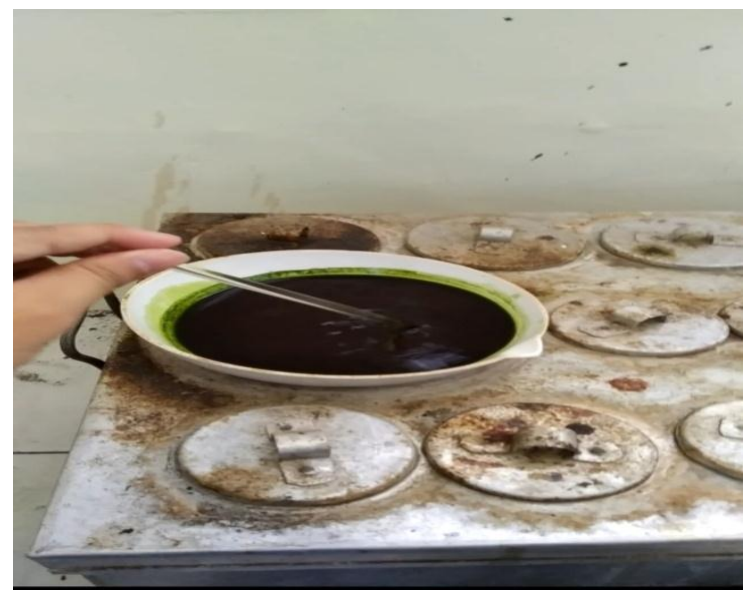

\section{Gambar 6. Proses Pemanasan diatas waterbath untuk memperoleh ekstrak kental}

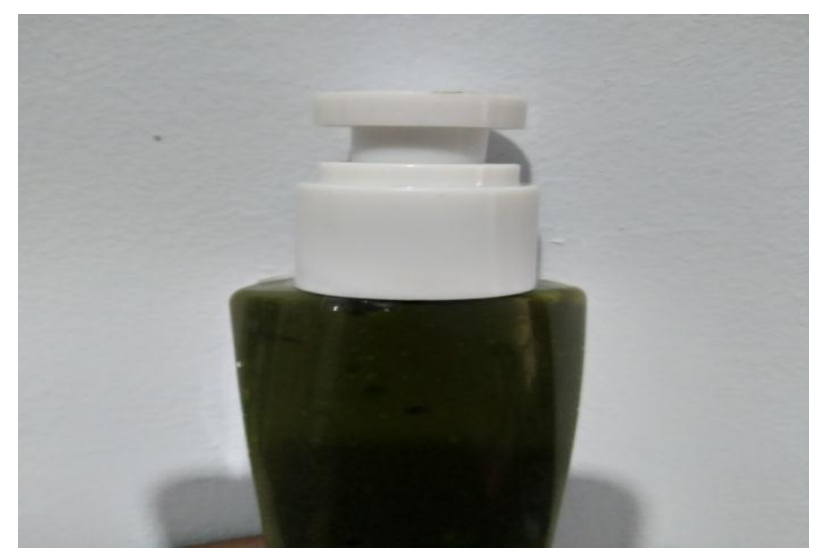

\section{Gambar 7. Hasil Hand Sanitizer Ekstrak daun sirsak}

Setelah terbentuk ekstrak etanol daun sirsak, maka dilakukan pembuatan gel hand sanitizer yaitu dengan menambahkan bahan-bahan yang sudah ditentukan dan hasilnya dimasukkan kedalam botol hand sanitizer seperti tertera pada gambar 7. Keseluruhan Proses 
tersebut didokumentasikan dalam bentuk video, yang kemudian ditayangkan pada saat Kegiatan 2 (Edukasi Warga melalui aplikasi Zoom Meeting).

\section{Kegiatan 2 (Edukasi Warga melalui aplikasi Zoom Meeting)}

Pada pelaksanaan webinar dengan melibatkan masyarakat sekitar dapat memahami materi yang disampaikan berupa edukasi tentang cara pembuatan hand sanitizer serta melakukan edukasi hal-hal terkait dengan penggunaan hand sanitizer. Pemahaman edukasi dapat dilihat dari sesi tanya jawab yang dilakukan pada saat webinar, respon masyarakat sangat baik dan aktif dengan memberikan beberapa pertanyaan yang berkaitan dengan hand sanitizer.

\section{Kegiatan 3 (Pemberian sampel hand sanitizer pada tetangga sekitar tempat tinggal)}

Setelah pelaksanaan webinar, masyarakat diberikan sampel hand sanitizer kepada tetangga sekitar tempat tinggal mahasiswa di Kecamatan Mundu, Kabupaten Cirebon, yang dilaksanakan pada 27-29 Agustus 2020. Hand sanitizer yang telah siap digunakan diberikan kepada masyarakat dengan mendatangi masing-masing rumah tetangga sekitar tempat tinggal. Dengan tetap memperhatikan dan mengikuti protokol kesehatan seperti memakai masker dan menjaga jarak.

\section{PEMBAHASAN}

Hasil yang diperoleh dari pembuatan ekstrak etanol daun sirsak dengan nilai rendemen 20,71\%. Untuk hasil dari pembuatan basis gel menghasilkan gel yang sedikit lebih kental dan pembuatannya membutuhkan waktu yang sedikit lebih lama karena menggunakan mortir yang digerus secara homogen bukan dengan menggunakan magnetic stirrer. Sedangkan untuk hasil dari pembuatan hand sanitizer daun sirsak menghasilkan hand sanitizer dengan warna hijau tua yang disebabkan oleh ekstrak daun sirsak yang berwarna hijau tua, tidak terlalu memberikan rasa dingin pada kulit karena tidak mengandung jumlah alkohol yang banyak dan bau yang kurang segar sehingga perlu ditambahkan dengan beberapa tetes pewangi untuk memperbaiki bau yang kurang segar tersebut.

Tahap berikutnya adalah edukasi hand sanitizer kepada masyarakat sekitar tempat tinggal mahasiswa. Adapun edukasi yang diberikan adalah tujuan penggunaan hand sanitizer yaitu untuk mengurangi patogen pada tangan. Pemakaian cairan pembersih berbasis alkohol lebih disukai daripada mencuci tangan menggunakan sabun dan air. Kandungan dari hand sanitizer yang dijelaskan kepada masyarakat meliputi bahan utama yang biasa digunakan sebagai hand sanitizer yang dapat melawan kuman/pathogen adalah alkohol, namun saat ini 
juga banyak peneliti yang telah menemukan bukan hanya alkohol yang dapat melawan pathogen/kuman pada tangan dan kulit, bisa juga menggunakan bahan-bahan herbal yang memiliki khasiat sebagai antiseptik atau antibakteri. Pada produk ini kami menggunakan ekstrak etanol daun sirsak serta mengurangi jumlah etanol yang digunakan pada produk hand sanitizer ini.

Edukasi mengenai cara penggunaan hand sanitizer yang baik dan benar yaitu penggunaan hand sanitizer yang benar dapat menggunakan istilah TEPU SELACI PUTPUT, yaitu meletakan hand sanitizer diTElapak tangan, meratakannya di PUnggung tangan kemudian SEla-sela jari, lakukan gerakan mengunCI, kemudian meMUTar kedua ibu jari, meMUTar ujung-ujung jari, dan yang terakhir adalah kedua pergelangan tangan

Beberapa hal yang perlu diperhatikan sebelum menggunakan hand sanitizer yaitu apabila terdapat tempat untuk mencuci tangan dengan sabun sebaiknya pilihlah utuk mencuci tangan dengan sabun dari pada menggunakan hand sanitizer karena hand sanitizer tidak bisa untuk melawan semua kuman. Hindari penggunaan hand sanitizer pada luka, karena bila digunakan pada kulit yang luka maka dapat menyebabkan reaksi alergi dan iritasi pada kulit. Tidak cocok digunakan untuk membersihkan sisa makanan terutama yang mengandung lemak dan gula. Hand sanitizer dapat mengiritasi kulit apabila digunakan terlalu sering, karena biasanya hand sanitizer mengandung alkohol walaupun ampuh untuk melawan kuman.

\section{KESIMPULAN DAN SARAN}

Daun sirsak dapat diformulasikan sebagai hand sanitizer sebagai salah satu cara untuk cuci tangan secara praktis dalam menghadapi kondisi pandemi Covid-19. Pelaksanaan webinar menunjukkan respon yang positif dengan adanya interaksi antara peserta dan penyelenggara webinar. Pemberian sampel hand sanitizer kepada tetangga sekitar, tujuannya agar mengetahui formulasi, cara pembuatan, tujuan, kandungan, cara pakai yang baik, dan hal yang perlu diperhatikan sebelum menggunakan hand sanitizer kepada masyarakat, khususnya Kecamatan Mundu, Kabupaten Cirebon.

\section{UCAPAN TERIMA KASIH}

Ucapan terimakasih kepada warga Kecamatan Mundu, Kabupaten Cirebon. 


\section{DAFTAR PUSTAKA}

Aminah Asngad, Aprilia Bagas R, Nopitasari., 2018. Kualitas Gel Pembersih Tangan Handsanitizer) dari Ekstrak Batang Pisang dengan Penambahan Alkohol, Triklosan dan Gliserin yang Berbeda Dosisnya. Jurnal Bioeksperimen, Volume 4, No.2. Hlm 61-70.

Cahyani, N. M. E. (2014). Daun Kemangi (Ocinum cannum) Sebagai Alternatif Pembuatan Handsanitizer. Jurnal Kesehatan Masyarakat. 9(2), pp. 136-142.

Hapsari, D. N. (2015). Pemanfaatan Ekstrak Daun Sirih (Piper Betle Linn) Sebagai Hand Sanitizer. Skripsi. Poltekkes Kemenkes Yogyakarta.

James, J. 2008. Prinsip-prinsip Sains untuk Keperawatan. Erlangga. Jakarta.

Manus Nuriko, Paulina V.Y, dkk., 2016. Formulasi Sediaan Gel Minyak Atsiri Daun Sereh (Cymbopogon Ciratus) Sebagai Antiseptik Tangan. Jurnal Ilmiah Farmasi. Vol. 5, No. 3. Hlm 86.

Mangan, Y. (2009). Solusi Sehat Mencegah Dan Mengatasi Kanker. Agromedia Pustaka, Jakarta.

Sjahid. L. R. (2008). Isolasi dan Identifikasi Flavonoid dari Daun Dewandaru (Bungenia uniflora L.). [Skripsi]. Fakultas Farmasi Universitas Muhamammadiyah, Surakarta.

Werenfridus Kono Lake, dkk., 2019. Uji Aktivitas Antibakteri dari Ekstrak n-Heksana dan Kloroform Daun Sirsak (Annona muricate L.) Terhadap Pertumbuhan Bakteri Staphylococcus aureus Secara In Vitro. Jurnal medik veteriner. Vol.2, No.1. Hlm 60-65.

Widyawati, L., Mustariani, B., \& Purmafitriah, E. (2018). Formulasi Sediaan Gel Hand Sanitizer Ekstrak Etanol Daun Sirsak (Annona muricate Linn) Sebagai Antibakteri Terhadap Staphylococcus aureus, Jurnal Farmasetis, 6(2), 47-57. 
